\title{
THE HEART IN TOXÆMIA OF PREGNANCY
}

\author{
BY \\ PAUL SZEKELY AND LINTON SNAITH
}

\begin{abstract}
From the Cardiovascular Department and the Department of Obstetrics, Newcastle General Hospital, Newcastle-upon-Tyne
\end{abstract}

Received November 28, 1946

Although acute pulmonary œdema is a recognized complication of toxæmia of pregnancy, its mechanism is incompletely understood. In some of the reported cases the clinical picture was similar to that of cardiac asthma and the cause of the pulmonary œdema was thought to be left ventricular failure. Detailed studies of the heart in toxæmia of pregnancy, however, have been few, and reports showing that toxæmia of pregnancy may be associated with myocardial damage are not many. Some of the cases of acute heart failure reported in late pregnancy and in the early puerperium in patients who had no signs of antecedent cardiovascular disease may have been instances of toxæmia with associated myocardial damage. Thus, Blacker (1907) and later Campbell (1923) noticed the occurrence of heart failure during and after pregnancy, and in the absence of a valvular lesion they regarded myocardial disease as the possible cause for it. Herrmann and King (1930) called attention to " significant types of cardiac failure occurring in pregnant patients with non-valvular heart disease." Toxæmia was apparently present in some of their patients.

Eufinger and Molz (1936) undertook a cardiographic study of 23 cases of toxæmia of pregnancy, but were unable to demonstrate myocardial disease. Gouley, McMillan, and Bellett (1937) observed heart failure and $T$ wave changes in the cardiogram shortly after delivery. Some of their patients died, and the histological examination showed focal myocardial necrosis; the coronary arteries were found to be normal. In two of the cases the blood pressure was raised, but in only one surviving case was toxæmia described by the authors. Teel, Reid, and Hertig (1937) reported 6 cases of toxæmia of pregnancy complicated by cardiac asthma and pulmonary cedema; one came to autopsy, and the histological sections of the heart showed cdema of the stroma and occasional cellular infiltration, with slight subendocardial fibrosis and occasional thickening of the internal elastic membrane of the smaller coronary branches. They concluded that the œdema and the leucocytic infiltration of the myocardial tissue were consistent with an acute process that could have interfered with the cardiac function. Hull and Hidden (1938), reporting on the occurrence of post-partum heart failure, mentioned toxæmia of pregnancy and nutritional deficiency as possible ætiological factors; hypertension with a systolic pressure above 150, was present in one third of their cases. Thomson, Cohen, and Hamilton (1938) studied chest lead cardiograms in pregnancy, including normal subjects and patients with heart disease or toxæmia, and found that an upright $T$ wave was usual in toxæmic patients (they used the old method of recording chest leads, according to which the $T$ wave was normally inverted): the $R$ wave was entirely absent or less than $2 \mathrm{~mm}$. in some of the toxæmic and cardiac patients, but never in the normal cases. Bradford (1939) stressed the danger of cardiac decompensation in acute pre-eclampsia. According to Dexter and Weiss (1941) and Dexter et al. (1943), the heart is usually normal when toxæmia is mild, but severe toxæmia with generalized œdema is frequently associated with 
heart failure. They found changes in 2 of 12 cardiograms, and in both the changes appeared in the post-partum period, on the 6th and 9th day respectively: in the second the cardiogram was normal 7 days before term when signs of heart failure were present, and it became abnormal later when the failure had subsided. Dieckmann (1942) stated that patients with mild toxæmia rarely showed evidence of cardiac damage, but those with severe pre-eclampsia and eclampsia usually had tachycardia and occasionally developed heart failure. Recently Wallace, Katz, Langendorf, and Buxbaum (1946) studied the cardiogram in 12 cases of pregnancy toxæmia and found changes similar to those seen in anterior myocardial infarction in 2, both of which had heart failure; 4 showed alterations in the $T$ wave and prolonged A-V conduction, but no clinical evidence of heart failure; and in the remaining 6 there was neither clinical nor cardiographic evidence of cardiac involvement.

\section{Personal Observations}

The present paper is based on the observations made in 19 unselected cases of toxæmia of pregnancy, delivered in the Department of Obstetrics of the Newcastle General Hospital. Although the difficulty of assessing the severity of the toxæmic state is fully recognized, an attempt has been made to classify the cases for the purposes of this study. The majority were classified as severe, the criteria being subjective symptoms, such as headache, vomiting, and visual disturbance, and height of blood pressure, œdema, albuminuria, and the occurrence of eclamptic fits. All the " severe" cases had a blood pressure of more than 160/100, in addition to other symptoms and signs of toxæmia, except one with a blood pressure of 130/95, classified as severe because of eclamptic convulsions.

Clinical and cardiographic studies were made in all and, in addition, radioscopic examination in 9 cases. The cardiovascular findings are summarized in Table I. A total of 7 cases were thought to show significant clinical and/or cardiographic changes. Left ventricular failure was observed in 3 (Cases 1, 13, and 19), and the first of these also showed $T$ wave changes similar to those seen in anterior myocardial infarction. Significant cardiographic changes were seen in 5 (Cases 1,8,11,17, and 18), these changes consisting of transient alterations of the $T$ waves usually in both standard and chest leads (Fig. 1-5). Cardiographic changes of doubtful significance were observed in 6 others. In the remaining 8 the cardiograms were within normal limits. Sinus tachycardia was frequent and extrasystoles were observed in 2 (Cases 17 and 19).

Case 1, para 3, aged 36. Admitted on 17/7/42 with œedema of the legs, albuminuria, and a B.P. of $185 / 120$. She had a normal labour and was delivered on 24/7/42. Three days later she developed acute pulmonary odema. There was marked tachycardia, triple rhythm, and slight papilloedema. The cardiogram (Fig. 1A) showed inverted $\mathrm{T}$ waves in the limb leads. The clinical condition gradually improved, the triple rhythm disappeared, and on 18/8/42 she had no signs of cardiac failure, no albuminuria, and no œedema. Her B.P. was 145/95. However, the cardiogram (Fig. 1B) was still very abnormal, showing inverted T wave in leads I, II, and IV. Radioscopic examination showed a normal-sized heart. On 4/9/42 the B.P. came down to 140/90. Repeated cardiograms were done, and a gradual increase in the voltage of the $T$ waves was noted. The tracing taken on 19/11/42 (Fig. 1C) showed a complete return to normal. The patient was seen three months later when she was complaining of headaches. Her heart was normal clinically, radiologically, and cardiographically, but her B.P. was 170/100 and the retinal vessels were thought to be slightly thickened.

Case 8, para 0, aged 21. Admitted on 22/9/44 complaining of headaches, dimness of vision, and eclamptic fits of three days' duration. She was delivered on 25/9/44. The highest blood pressure was recorded on the second post-partum day when it was 180/110. The first cardiogram (Fig. 2A), taken on 27/9/44, showed $T$ wave changes and small $\mathbf{R}$ wave in lead $\mathbf{C R}_{\mathbf{2}}$. Another taken 7 days later showed improvement (Fig. 2B). Her B.P. came down to 120/85. The albuminuria and œedema had disappeared, and radioscopic examination showed a normal-sized heart. The patient was seen

L 
again in March 1945, when her B.P. was $120 / 80$ and the clinical, radiological, and cardiographic findings were also normal.

Case 11, para 10, aged 38. Admitted on 6/10/44 with marked œdema of the legs, albuminuria, and a B.P. of 200/140. She was delivered on 12/10/44 by Cesarean section. On 14/10/44 her B.P. was $160 / 100$ and there was a slight papillodema. Clinically, the heart was normal. However, a cardiogram taken on the same day (Fig. 3A) showed flat $T$ wave in leads II and IVR, and inverted T wave in leads III and $\mathrm{CR}_{2}$; the initial deflection was absent in $\mathrm{CR}_{2}$; and the electrical systole was prolonged. Fig. 3B, taken on 18/10/44, showed improvement. On 25/10/44 the cardiogram still showed an absent $R$ wave in lead $C_{2}$, but otherwise it was normal (Fig. 3C). On radioscopic examination, the heart was normal in size. The optic discs looked normal. There was no odema and no albuminuria; the B.P., however, remained 160/100.

Case 13, aged 34. Admitted on 15/12/44 with œdema of legs, albuminuria, and a B.P. of 160/100. She was delivered on 24/12/44. On 6/1/45 she was found to have tachycardia, triple rhythm, and evidences of pulmonary congestion. The retinal vessels looked normal, and the B.P. was 150/100.

TABLE I

Cardiovascular findings in Toxamia of Pregnancy

\begin{tabular}{|c|c|c|c|c|c|c|c|c|}
\hline \multirow{2}{*}{$\begin{array}{l}\text { Case } \\
\text { No. }\end{array}$} & \multirow{2}{*}{ Age } & \multirow{2}{*}{ Toxæmia } & \multirow{2}{*}{$\underset{\text { (maximum) }}{\text { B.P. }}$} & \multicolumn{3}{|c|}{ Heart } & \multirow{2}{*}{$\begin{array}{l}\text { Electro- } \\
\text { cardiogram }\end{array}$} & \multirow{2}{*}{ Remarks } \\
\hline & & & & Rate & Sounds & Size & & \\
\hline $\begin{array}{c}1 \\
\text { (Fig. 1) }\end{array}$ & 36 & Severe & $185 / 120$ & 140 & $\begin{array}{l}\text { Triple } \\
\text { rhythm }\end{array}$ & $\begin{array}{c}\text { Normal } \\
\text { (X-ray) }\end{array}$ & $\begin{array}{l}\text { Inverted TI, TII, } \\
\text { TIV }\end{array}$ & $\begin{array}{l}\text { Left ventricular } \\
\text { failure }\end{array}$ \\
\hline $\begin{array}{l}2 \\
3\end{array}$ & $\begin{array}{l}29 \\
29\end{array}$ & $\begin{array}{l}\text { Mild } \\
\text { Severe } \\
\text { eclampsia }\end{array}$ & $\begin{array}{l}160 / 100 \\
170 / 100\end{array}$ & $\begin{array}{l}88 \\
80\end{array}$ & $\begin{array}{l}\text { Normal } \\
\text { Normal }\end{array}$ & $\begin{array}{r}\text { Normal } \\
\text { Normal } \\
\text { (X-ray) }\end{array}$ & $\begin{array}{l}\text { Normal } \\
\text { Low TII. In- } \\
\text { verted TIII. } \\
\text { Low TIV }\end{array}$ & = \\
\hline $\begin{array}{l}4 \\
5\end{array}$ & $\begin{array}{r}.34 \\
25\end{array}$ & $\begin{array}{l}\text { Severe } \\
\text { Severe }\end{array}$ & $\begin{array}{l}180 / 130 \\
190 / 130\end{array}$ & $\begin{array}{r}60 \\
100\end{array}$ & Normal & $\begin{array}{l}\text { Normal } \\
\text { Normal }\end{array}$ & $\begin{array}{l}\text { Normal } \\
\text { Normal }\end{array}$ & 二 \\
\hline 6 & 22 & $\begin{array}{l}\text { Severe } \\
\text { eclampsia }\end{array}$ & $130 / 95$ & 130 & Normal & Normal & Normal & 一 \\
\hline 7 & 32 & Severe & $160 / 110$ & 120 & Normal & Normal & $\begin{array}{l}\text { Low TI. Isoelec- } \\
\text { tric TIV }\end{array}$ & 一 \\
\hline $\begin{array}{c}8 \\
\text { (Fig. 2) }\end{array}$ & 21 & $\begin{array}{l}\text { Severe } \\
\text { eclampsia }\end{array}$ & $180 / 110$ & 80 & Normal & $\begin{array}{c}\text { Normal } \\
\text { (X-ray) }\end{array}$ & $\begin{array}{l}\text { Isoelectric TI. In- } \\
\text { verted TIV }\end{array}$ & - \\
\hline 9 & 29 & Severe & $180 / 110$ & 90 & $\begin{array}{l}\text { Normal. } \\
\text { Apical } \\
\text { S.M. }\end{array}$ & Normal & $\begin{array}{l}\text { Depressed S-TIV. } \\
\text { Low TIV. RIV } \\
<2 \mathrm{~mm} .\end{array}$ & 二 \\
\hline 10 & $\begin{array}{l}23 \\
38\end{array}$ & Mild & $160 / 100$ & 70 & Normal & Normal & Normal & , Antecēen \\
\hline (Fig. 3) & 38 & Severe & $200 / 140$ & 110 & Normal & $\begin{array}{c}\text { Normal } \\
\text { (X-ray) }\end{array}$ & $\begin{array}{l}\text { Isoelectric } \\
\text { III. } \\
\text { and TIV } \\
\text { and TIII }\end{array}$ & $\begin{array}{l}\text { ? Antecedent hyper- } \\
\text { tension. Cæsarean } \\
\text { section. }\end{array}$ \\
\hline 12 & 23 & Mild & $160 / 100$ & 90 & Normal & $\begin{array}{c}\text { Normal } \\
\text { (X-ray) }\end{array}$ & Low TIV & $\begin{array}{l}\text { ? Antecedent hyper- } \\
\text { tension. Died of } \\
\text { uræmia six months } \\
\text { later }\end{array}$ \\
\hline 13 & 34 & Mild & $160 / 100$ & 100 & $\begin{array}{c}\text { Triple } \\
\text { rhythm }\end{array}$ & $\underset{\text { (X-ray) }}{\text { LV+ }}$ & Normal & $\begin{array}{l}\text { Left ventricular } \\
\text { failure; ? ante- } \\
\text { cedent hyperten- } \\
\text { sion }\end{array}$ \\
\hline $\begin{array}{l}14 \\
15\end{array}$ & $\begin{array}{l}36 \\
31\end{array}$ & $\begin{array}{l}\text { Mild } \\
\text { Severe }\end{array}$ & $\begin{array}{l}150 / 100 \\
170 / 105\end{array}$ & $\begin{array}{l}70 \\
80\end{array}$ & $\begin{array}{l}\text { Normal } \\
\text { Normal }\end{array}$ & $\begin{array}{l}\text { Normal } \\
\text { Normal }\end{array}$ & $\begin{array}{l}\text { P-R+ } \\
\text { Normal }\end{array}$ & - \\
\hline 16 & 32 & Severe & $175 / 115$ & 90 & Normal & Normal & $\mathrm{RIV}<2 \mathrm{~mm}$ & $\begin{array}{l}\text { Delivered by Cæsar- } \\
\text { ean section }\end{array}$ \\
\hline $\begin{array}{c}17 \\
\text { (Fig. 4) }\end{array}$ & 21 & $\begin{array}{l}\text { Severe } \\
\text { eclampsia }\end{array}$ & $210 / 140$ & 130 & Normal & $\begin{array}{c}\text { Normal } \\
\text { (X-ray) }\end{array}$ & $\begin{array}{l}\text { Low TI. } \\
\text { ed TIV. } \\
\text { systolest- }\end{array}$ & $\begin{array}{l}\text { Post-partum vascu- } \\
\text { lar collapse }\end{array}$ \\
\hline $\begin{array}{c}18 \\
\text { (Fig. 5) }\end{array}$ & 21 & Severe & $200 / 150$ & 100 & Normal & $\underset{\text { (X-ray) }}{\text { Normal }}$ & $\begin{array}{l}\text { Isoelectric TII. } \\
\text { Inverted TIII and } \\
\text { TIV }\end{array}$ & - \\
\hline 19 & 31 & Severe & $200 / 110$ & 100 & $\begin{array}{l}\text { Triple } \\
\text { rhythm }\end{array}$ & $\begin{array}{c}\text { Normal } \\
\text { (X-ray) }\end{array}$ & Normal & $\begin{array}{l}\text { Left ventricular } \\
\text { failure }\end{array}$ \\
\hline
\end{tabular}




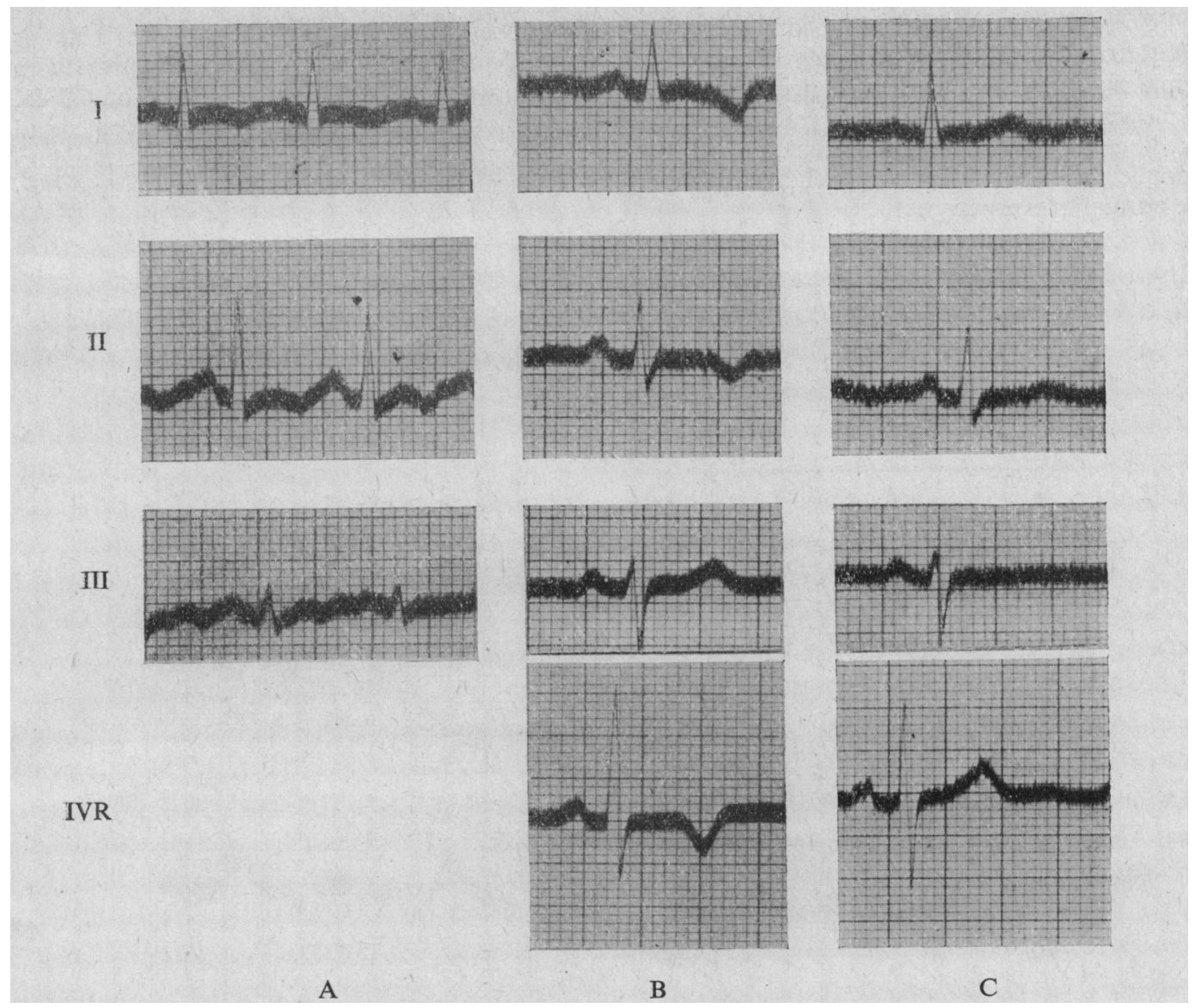

Fig. 1.-Case 1. Toxæmia complicated by left ventricular failure. Delivered on 24/7/42. (A) 27/7/42; abnormal T waves. (B) 18/8/42; deeply inverted T wave in leads I, II, and IV. (C) $19 / 11 / 42$; normal tracing.

A cardiogram showed left axis deviation and normal complexes. The radioscopic examination showed slight enlargement of the left ventricle. The patient made a good recovery, the triple rhythm and the pulmonary congestion had disappeared. She was discharged and a follow-up was, unfortunately, impossible.

Case 17, para 0, aged 21. Admitted on 9/4/46 with eclampsia, albuminuria, and œdema of legs and face. Her B.P. was 210/140. She was delivered on the same day. Twelve hours after delivery she showed evidences of a vascular collapse, the heart rate being 130 a minute and the B.P. 90/70. The patient had only a very slight loss of blood, which could not account for the collapse. She was given blood and plasma transfusions and she gradually improved. On 11/4/46 her B.P. was 130/90. Fig. 4A showed flat $T$ II and inverted $T$ in leads III and $C_{2}$. There was some improvement in Fig. 4B and $C$, taken five and nine days later.

Case 18, para 0, aged 21. Admitted on 12/4/46 with severe albuminuria and œdema of legs. The B.P. was 200/150, and there was a slight papillodema. She was delivered on 16/4/46. Fig. 5A, taken the next day, showed the T waves flat in leads II and IVR, and inverted in leads III and CR $_{2}$. Clinically the heart was normal. The B.P. was $170 / 145$, on the same day and on $23 / 4 / 46$ had fallen to 150/120. The cardiogram (Fig. 5B) showed higher $T$ waves. On 27/4/46 the B.P. was 130/90 and the optic discs looked normal. The cardiogram showed no abnormality (Fig. 5C), and on screen examination the heart was normal in size. Also the œdema and albuminuria had completely cleared up. 
Case 19, para 4, aged 31. Admitted on 28/6/46 with severe œdema of the legs. The B.P. was 200/110. On $2 / 7 / 46$ she suddenly became very dyspnœic, and was found to have tachycardia with triple rhythm and pulmonary congestion. No cardiogram was done. She was delivered on 6/7/46. Following delivery, there was a gradual improvement, and on 18/7/46 the clinical, cardioscopic, and cardiographic findings were normal. Her B.P. was 130/80, and the œdema of the legs had cleared up completely. The patient was seen again a month later, when the cardiovascular system was found to be normal in every respect.

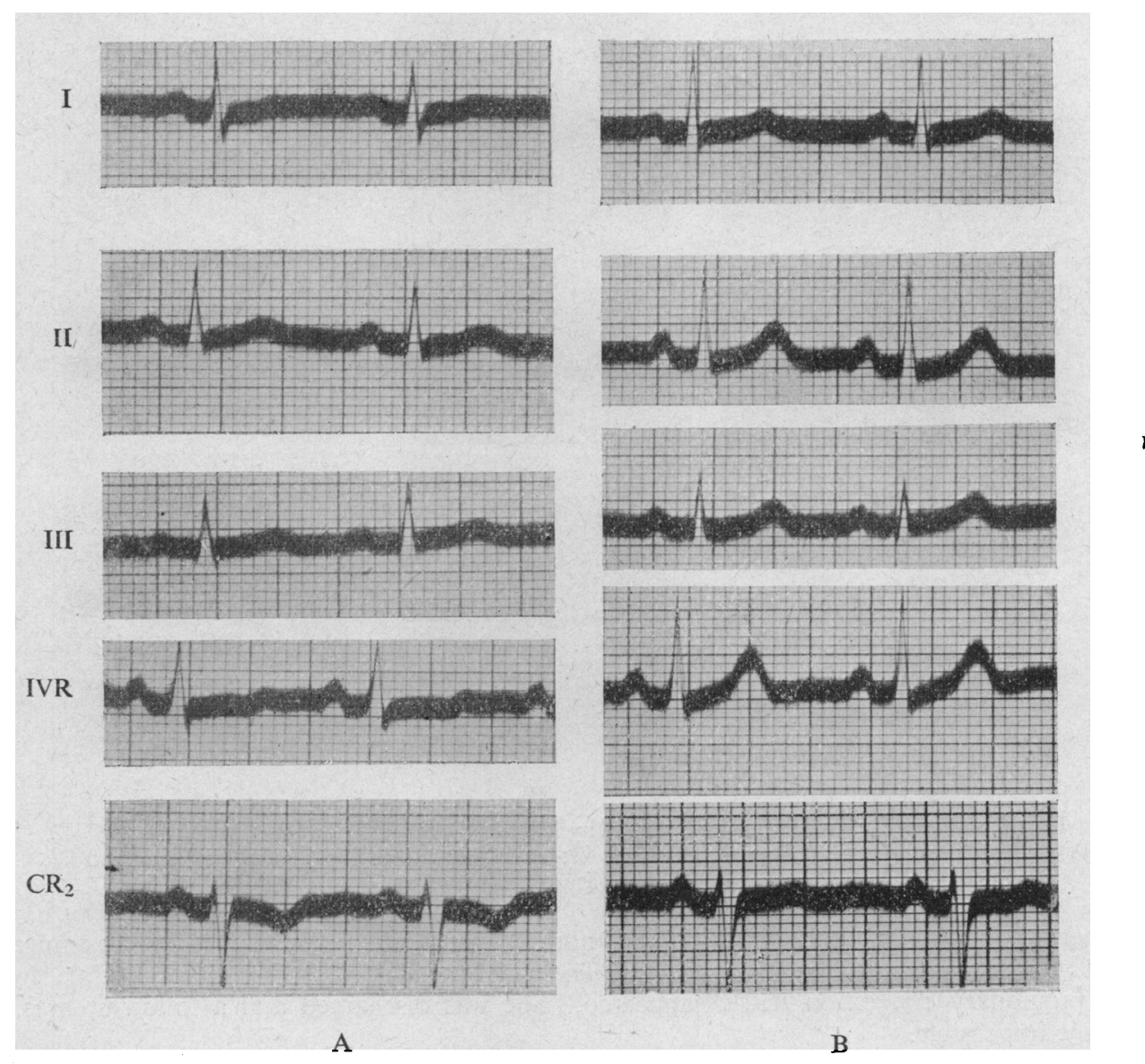

FIG. 2.-Case 8. Eclampsia. Delivered on 25/9/44.

(A) 27/9/44; flat or inverted $\mathrm{T}$ waves. (B) $9 / 10 / 44$; $\mathrm{T}$ waves returning to normal.

\section{Discussion}

In the present series a total of 7 patients (37 per cent) were thought to have significant changes in the heart: 2 showed clinical changes only, 4 cardiographic changes only, and 1 showed both clinical and cardiographic evidence of cardiac involvement. This incidence of cardiac involvement in toxæmia of pregnancy is somewhat lower than that recently reported by Wallace et al. (1946), who found cardiac changes in 6 of 12 cases.

Thomson, Cohen, and Hamilton (1938) observed transient abnormality of the $T$ wave in the chest lead in some of their normal pregnant patients. Wallace et al. (1946), found an inverted $T$ wave in lead $C_{2}$ in a pregnant woman whose heart was believed to be normal, and suggested that such inversion of $\mathrm{T}$ in the chest lead may occur in normal pregnancy. 
As regards our present series, we believe that the cardiographic changes were indicative of myocardial damage in at least 5 cases, because they occurred in both standard and chest leads, and persisted for some time after delivery, so that the alteration in the anatomical position of the heart during pregnancy could be excluded as causative factors. Furthermore, one of us (P.S.) has examined the records of several pregnant women, including patients with normal hearts, with chronic rheumatic heart disease, and with permanent arterial hypertension

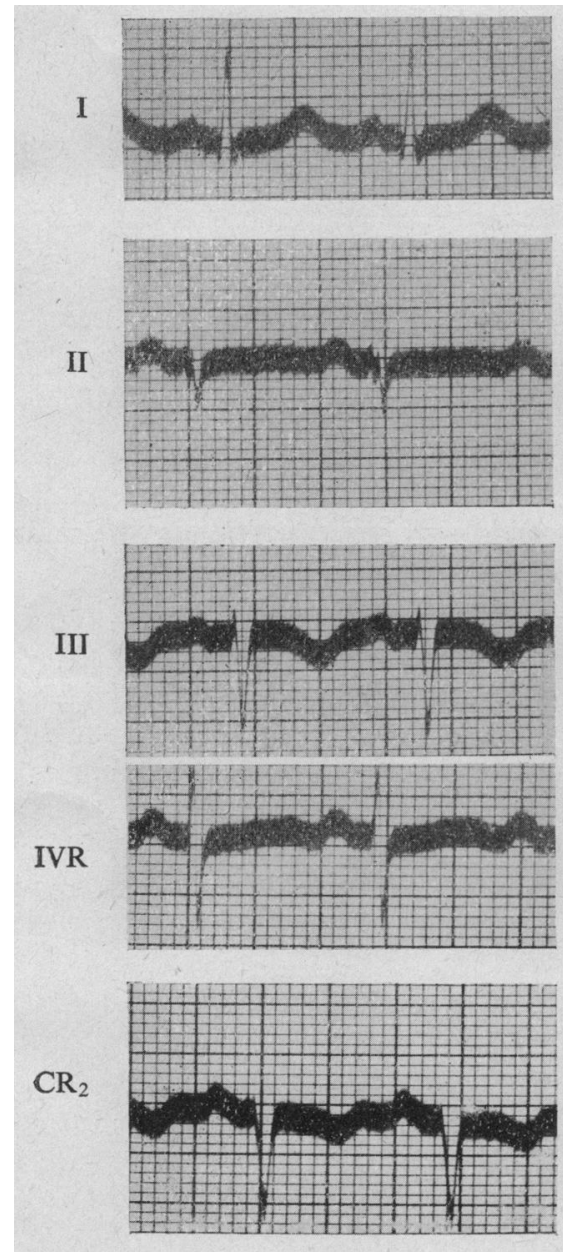

A
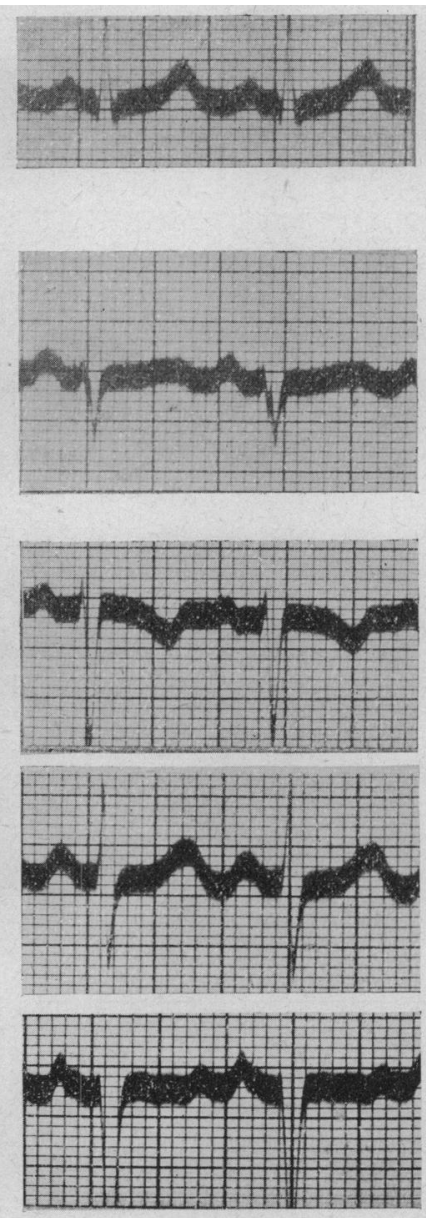

B
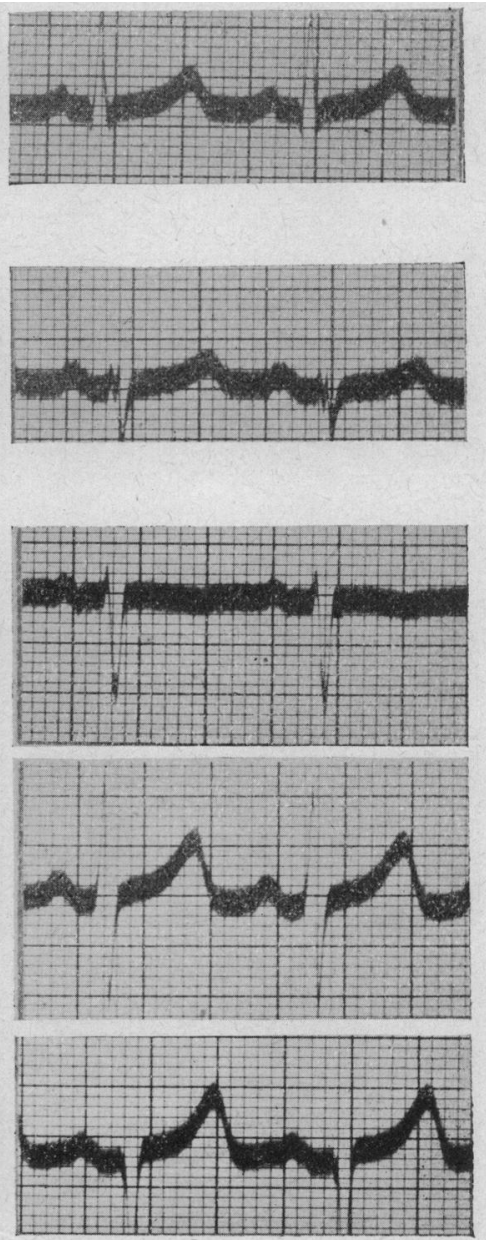

$\mathrm{C}$

Fig. 3.-Case 11. Probable chronic hypertension with superimposed toxæmia. Delivered by Cæsarean section on 12/10/44.

(A) 14/10/44; definite $T$ wave changes, absent $R$ wave in $C_{2}$, prolonged electrical systole. (B) 18/10/44; $T$ waves getting higher. (C) $25 / 10 / 44$; still absent $R$ wave in $C_{2}$, otherwise normal tracing.

without superimposed toxæmia, both ante-partum and post-partum, and has not observed a sequence of cardiographic changes similar to those seen in some of the toxæmic patients.

The changes in the heart appear to be temporary, but their duration varies considerably. The changes may not only persist for some time after delivery, but may become greater in the post-partum period. This has been previously stressed by Dexter and Weiss (1941) and Wallace et al. (1946), and is also borne out by our own observations. 
Although it is highly probable that there is a causal relationship between toxæmia of pregnancy and cardiac damage, it is not quite clear how the latter is brought about. According to Dexter and Weiss (1941) the syndrome of cardiac asthma and pulmonary edema may be caused by two factors, singly or combined-primary fluid retention in the lung tissue caused by factors specific to toxæmia, and left ventricular failure-and the mechanism of pulmonary

I

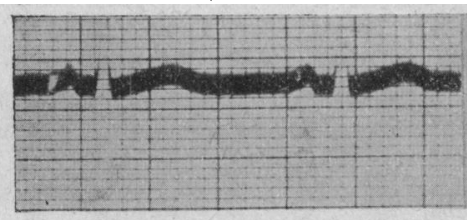

II

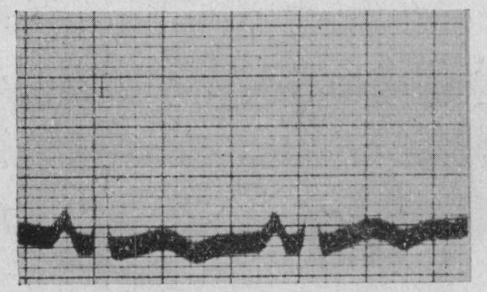

III

IVR

$\mathrm{CR}_{2}$
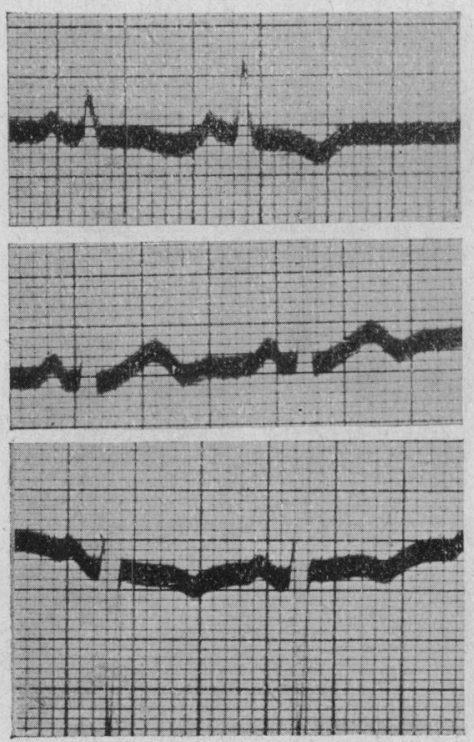

A
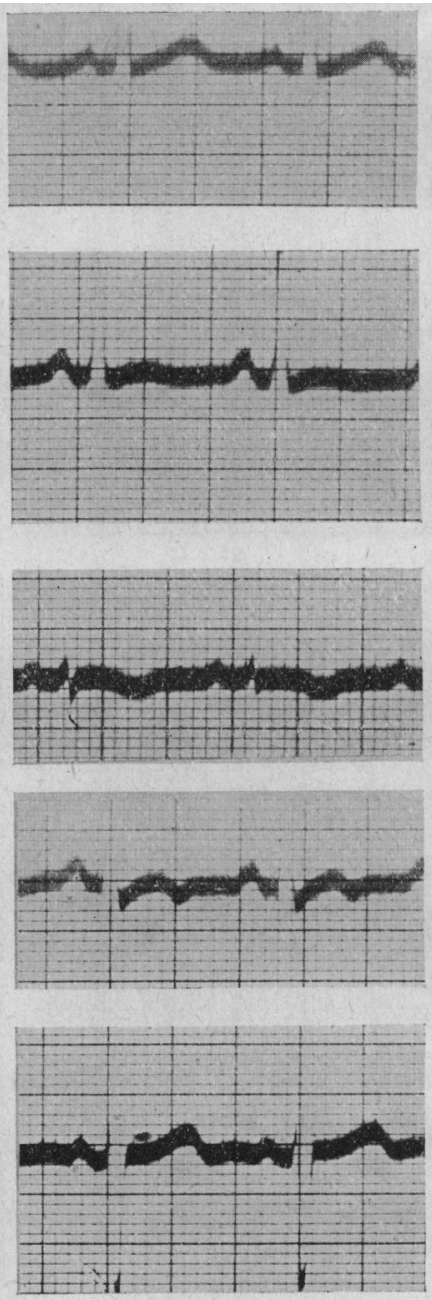

B
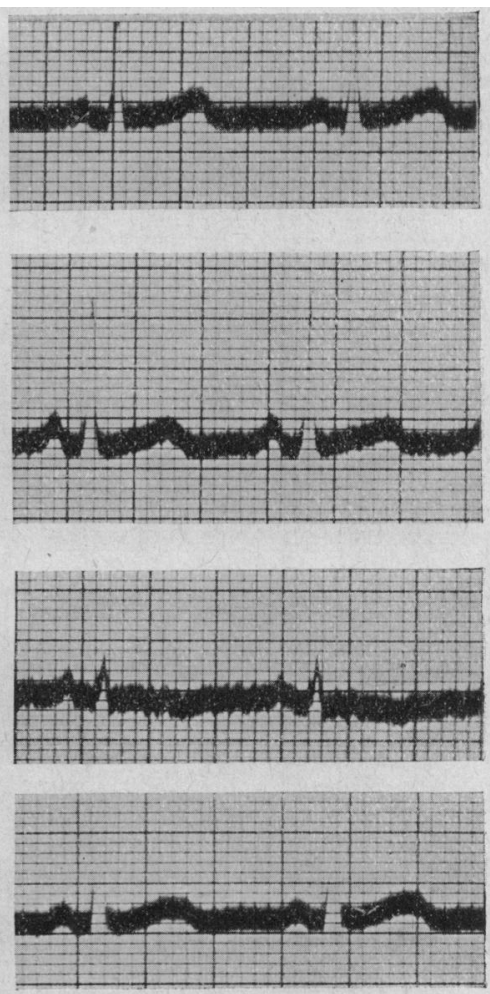

C

Fig. 4.-Case 17. Eclampsia. Delivered on 9/4/46. Post-partum vascular collapse.

(A) 11/4/46; $T$ wave changes, extrasystole in lead III. (B) 16/4/46; $T$ in $\mathrm{CR}_{2}$ positive, but still abnormal tracing. (C) 20/4/46; T waves returning to normal.

œdema in toxæmia of pregnancy is in many respects similar to that in beri-beri. Although there are some reports suggesting a causal relationship between toxæmia of pregnancy and vitamin $B_{1}$ deficiency (Siddall, 1940; King and Ride, 1945), the clinical and especially the cardiographic features of myocardial injury in toxæmia are unlike those seen in beri-beri heart disease.

Dieckmann (1942) found that in pre-eclampsia especially if severe, there is a concentration of blood during the height of the disease and dilution with clinical improvement. According 
to him hæmo-concentration places a tremendous strain on the heart because the thickened blood with increased viscosity requires more work by the heart and at the same time favours a decrease in the coronary circulation. Wallace et al. (1946) are of the opinion that focal myocardial necrosis, œdema, and infiltration are the essential factors in producing the cardiographic changes and precipitating the heart failure.

While the cardiac failure of the left ventricular type may be in some cases the direct result of the hypertension, it is unlikely that the latter condition is responsible for the cardiographic

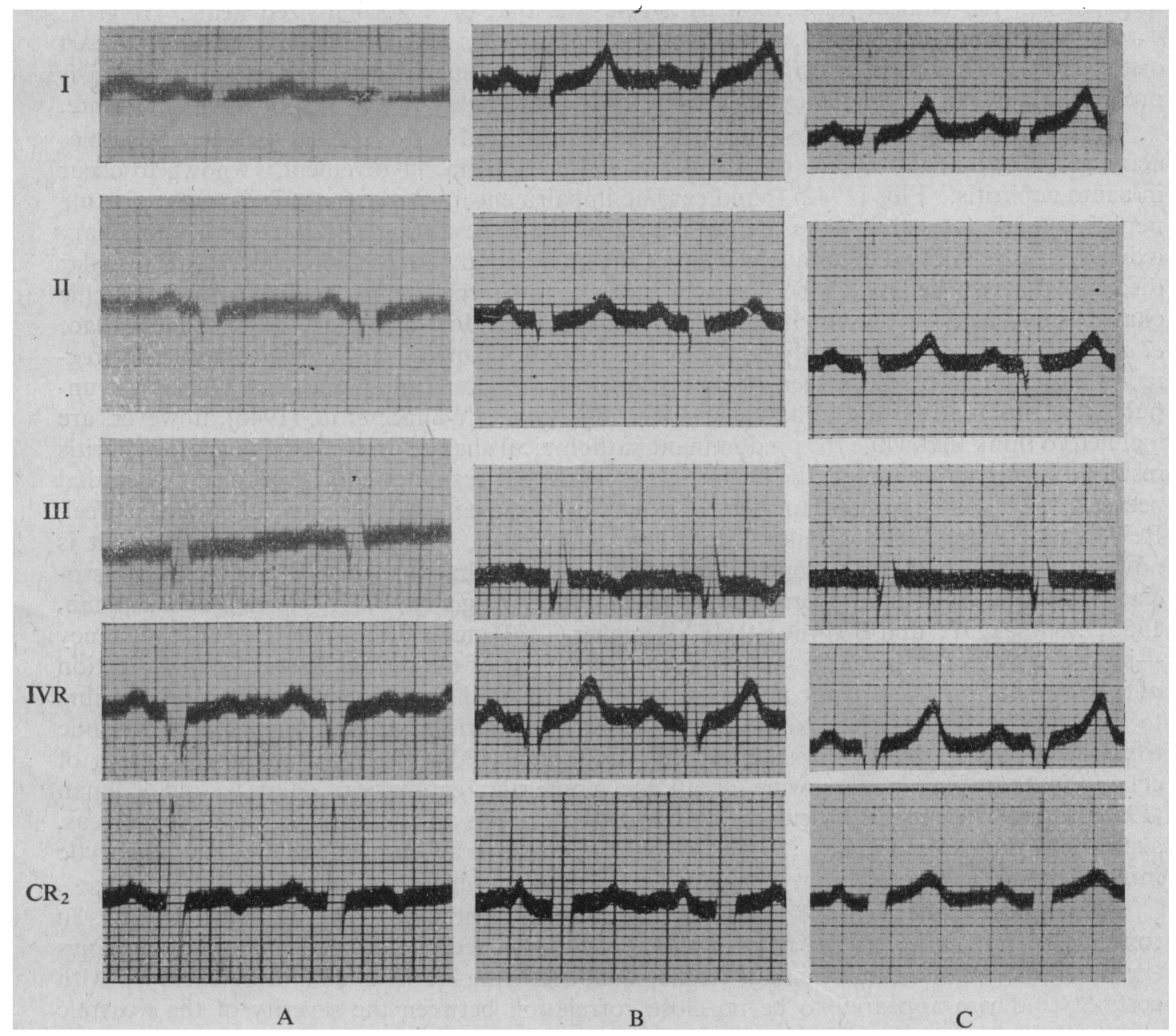

Fig. 5.-Case 18. Severe toxæmia. Delivered on 16/4/46.

(A) 17/4/46; marked $T$ wave changes. (B) 23/4/46; T waves getting higher. (C) $27 / 4 / 46$; normal tracing.

changes. The rise in the blood pressure in pure toxæmia or in patients with antecedent hypertension and superimposed toxæmia is usually not of sufficient duration to be an ætiological factor. On the other hand, the changes, if any, in persistent hypertension would not be limited to the period of pregnancy and the puerperium. One can assume, therefore, that the cardiographic abnormalities indicate changes in the heart that have a direct bearing on the "toxæmic" state. We have recently had the opportunity of following up a 28-year-old primigravida who had coarctation of the aorta with a blood pressure of $220 / 130$ in the upper 
extremities and enlargement of the left ventricle. There was nothing to suggest a superimposed toxæmia. Frequent cardiograms were done, including IVR and $\mathbf{C R}_{2}$ chest leads, from early pregnancy to the puerperium, and all records were strictly normal.

It would appear from our observations that gross cardiac enlargement is not a feature of pure "toxæmic" cardiac lesion, irrespective of the presence or absence of cardiac failure. Only one of our cases (Case 13) showed enlargement of the left ventricle. It is true that the radioscopic examination in many of our cases was not carried out at the height of the disease; nevertheless, the clinical impression as a rule was that of a normal-sized heart. If gross cardiac enlargement is present, it probably indicates either antecedent hypertension or heart disease not "toxæmic" in origin. There is nothing to suggest that pericardial effusion is present in toxæmia of pregnancy to account for the cardiographic changes or the heart failure.

Toxæmia of pregnancy is an acute vascular disorder and in this respect it closely resembles acute glomerulo-nephritis (Dexter and Weiss, 1941). Cardiac involvement is known to occur in acute nephritis. Ellis (1942) found cardiac impairment in 21 per cent of his cases of acute nephritis, and states that " the picture is that of the left ventricular failure with pulmonary œedema; it is possibly due to involvement of the myocardial vessels in the widespread vascular disorder that we believe to be characteristic of this type of nephritis." Cardiographic changes may also be present in acute nephritis (Langendorf and Pick, 1938), and Wallace et al. (1946) pointed out recently that the cardiographic changes observed in toxæmia of pregnancy are similar to those seen occasionally in acute glomerulo-nephritis. Our as yet unpublished observations are in agreement with this view. Wallace et al. (1946), however, are inclined to think that while the predominant pathological changes in the heart in acute nephritis result from vascular damage, the changes in toxæmia of pregnancy consist of focal myocardial necrosis. This is supported to a great extent by the available pathological findings (Teel, Reid, and Hertig, 1937; Gouley, McMillan, and Bellett, 1937). On the other hand, it is now well established, both clinically and anatomically, that toxæmia of pregnancy is associated with generalized vascular changes (Bell, 1932; Wagener, 1933; Herrick and Tillman, 1935; Jones, 1937; and Browne, 1944). Wagener (1933) states that in "toxæmia of pregnancy - just as in glomerulo-nephritis - the presence of lesions of the retinal arteries is an indication of involvement of the systemic and renal arterioles of similar type and severity." According to Browne (1944) arteriolar spasm can be seen in the arterioles of the retina in pre-eclamptic toxæmia when the blood pressure exceeds 150 . Bell (1932) showed that in fatal cases of eclampsia there was a narrowing of all the glomerular capillaries. Herrick and Tillman (1935) found widespread vascular changes in the arteries of the kidneys, spleen, pancreas, suprarenal glands, and liver. Teel et al. (1937) found, in addition to odema and leucocytic infiltration of the myocardium, also minor changes in the small coronary vessels.

Although convincing proof is still lacking of a direct damage to the myocardial vessels in toxæmia of pregnancy, in the light of the above-mentioned clinical and anatomical findings the possibility of structural damage to the small coronary branches cannot be excluded with certainty. There appeared to be no close correlation between the severity of the toxæmic state and the degree of cardiac damage. The duration of the toxæmia may be more important than its severity in producing the cardiac damage.

The true significance of the observations presented in this paper lies in showing that cardiac involvement is not uncommon in toxæmia of pregnancy. We believe that some of the cases of acute ante-partum or post-partum cardiac failure of undetermined ætiology may be instances of toxæmia, even if the recognized signs of the latter condition are not convincingly present at the time of the onset of the cardiac failure; and that some of the cases of vascular collapse known as "obstetric shock" may be instances of true toxæmia. The clinical picture of postpartum vascular collapse in one of our cases (Case 17) was identical with that of so-called " obstetric shock." Most such cases are associated with traumatic delivery and post-partum 
loss, and the chief causative factor is blood loss. There remain, however, those infrequent but important cases where collapse occurs with minimal loss after normal labour and delivery, our Case 17 being an example. Such cases may be instances of toxæmia of pregnancy with associated myocardial damage.

\section{SUMmARY AND CONCLUSIONS}

The heart was studied in 19 unselected cases of toxæmia of pregnancy. Clinical and cardiographic examinations were made in all of them, and 9 were also studied radiologically.

Seven patients showed significant cardiac involvement. One developed left ventricular failure, with $\mathrm{T}$ wave changes in the cardiogram similar to those seen in anterior myocardial infarction. Two had left ventricular failure with normal cardiographic tracings. Four others showed no clinical evidence of cardiac failure, but their cardiograms showed $T$ wave changes that were interpreted as indicating myocardial damage, and one of these developed postpartum vascular collapse. Six patients showed cardiographic changes of doubtful significance, and in six both the clinical and the cardiographic findings were perfectly normal.

The clinical and cardiographic manifestations were of a transient nature. Cardiac enlargement was found in only one case, and the belief is expressed that gross cardiac enlargement is not a feature of pure " toxæmic" cardiac lesion irrespective of the presence or absence of cardiac failure.

The pathogenesis of the cardiac lesion is discussed, and it is suggested that either direct vascular damage-as in acute glomerulo-nephritis-or primary focal myocardial necrosis, or both, have to be considered.

Cardiac involvement is not an uncommon complication of toxæmia of pregnancy, and some of the unusual types of heart failure occurring in late pregnancy and in the early puerperium, and also some of the cases of post-partum vascular collapse may be instances of toxæmia of pregnancy with associated myocardial damage.

Our thanks are due to Professor W. E. Hume and to Dr. William Evans for their help and suggestions. We also wish to thank Dr. W. S. Walton, Medical Officer of Health, Newcastle-upon-Tyne, and Dr. G. Hurrell, Medical Superintendent, Newcastle General Hospital, for facilities provided.

\section{REFERENCES}

Bell, E. T. (1932). Amer. J. Path., 8, 1.

Blacker, G. F. (1907). Brit. med. J., 1, 1225.

Bradford, W. Z. (1939). Amer. J. Obst. Gynec., 38, 574.

Browne, F. J. (1944). Edinb. med. J., 51, 449.

Campbell, D. G. (1923). Quoted by Gouley et al. (1937).

Dexter, L., and Weiss, S. (1941). Preeclamptic and Eclamptic Toxemia of Pregnancy. Little and Brown Company, Boston.

-, Weiss, S., Haynes, F. W., and Sise, H. S. (1943). J. Amer. med. Ass., 122, 145.

Dieckmann, W. J. (1942). The Toxamias of Pregnancy. Henry Kimpton, London.

Ellis, A. (1942). Lancet, 1, 1, 34, and 72.

Eufinger, H., and Molz, H. (1936). Mschr. Geburtsh. Gynäk., 102, 17.

Gouley, B. A., McMillan, T. M., and Bellett, S. (1937). Amer. J. med. Sci., 194, 185.

Herrick, W. W., and Tillman, A. J. B. (1935). Arch. intern. Med., 55, 643.

Herrmann, G., and King, E. L. (1930). J. Amer. med. Ass., 95, 1472.

Hull, E., and Hidden, E. (1938). South. med. J., 31, 265.

Jones, G. M. (1937). Proc. Roy. Soc. Med., 30, 1286.

King, G., and Ride, L. T. (1945). J. Obst. Gynaec. Brit. Emp., 52, 130.

Langendorf, R., and Pick, A. (1938). Acta med. Scand., 94, 1.

Reid, D. E., and Teel, H. M. (1939), J. Amer. med. Ass., 113, 1628.

Siddall, A. C. (1940). Amer. J. Obst. Gynec., 39, 818.

Teel, H. M., Reid, D. E., and Hertig, A. T. (1937). Surg., Gynec., and Obst., 64, 39.

Thomson, K. J., Cohen, M. E., and Hamilton, B.E. (1938). Amer. J. med. Sci., 196, 819.

Wagener, H. P.'(1933). J. Amer. med. Ass., 101, 1380.

Wallace, L., Katz, L. N., Langendorf, R., and Buxbaum, H. (1946). Arch. intern. Med., 77, 405. 